\title{
PERANAN MEDIA PEMBELAJARAN DALAM MENINGKATKAN MINAT BELAJAR MAHASISWA
}

\author{
Talizaro Tafonao \\ Program Studi Pendidikan Agama Kristen, STT KADESI Yogyakarta \\ Email: talizarotafonao@gmail.com
}

\begin{abstract}
Abstrak
Perkembangan teknologi yang semakin canggih menjadi sarana penting untuk mencapai tujuan pendidikan yang lebih efektif dan efesien. Namun di balik itu menjadi tuntutan besar bagi para dosen/guru untuk mengembangkan kemampuan dalam menguasai teknologi dan media pembelajaran. Peranan media pembelajaran dalam proses belajar dan mengajar sangat penting dilaksanakan oleh para pendidik saat ini, karena peranan media pembelajaran dapat digunakan untuk menyalurkan pesan pengirim kepada penerima dan melalui media pembelajaran juga dapat membantu peserta didik untuk menjelaskan sesuatu yang disampaikan oleh pendidik. Oleh karena itu, dosen/guru dituntut untuk menggunakan media di dalam proses pembelajaran. Dengan demikian, melalui media pembelajaran dapat membuat proses belajar mengajar lebihefektif dan efesien serta terjalin hubungan baik antara guru dengan peserta didik. Selain itu, media dapat berperan untuk mengatasi kebosanan dalam belajar di kelas. Jadi media pembelajaran adalah salah satu metode dalam mengatasi segala macam persoalan dalam mengajar, bukan saja mengatasi persoalan, namun media pemberi pembelajaran memberi berbagai informasi yang koprehensip kepada peserata didik.
\end{abstract}

Kata-kata kunci: media pembelajaran, minat belajar mahasiswa

\section{THE ROLE OF INSTRUCTIONAL MEDIA TO IMPROVING STUDENT INTEREST}

\author{
Talizaro Tafonao \\ Study Program of Christian Education, STT KADESI Yogyakarta \\ Email: talizarotafonao@gmail.com
}

\begin{abstract}
The development of technology becomes important to achieve the goal of education, more effective and efficient. In another side, a big demand for the lecturers / teachers to develop their skills in technology and learning how to use media for their class. Nowdays the role teacher/lecturer with skill in technology in teaching and learning process is very important. Because to explain by technology is one one of great option in education, with alot of media that can be use, depend on the situation. Therefore, lecturers / teachers are required to be able use the media in the learning process. Thus, through the media can make the learning process more effective and efficient and also give another kind of relationship between teachers and students. In addition, the media can play a role to overcome the boredom in class. So the learning media is one of the methods in overcoming all kinds of problems in teaching, not only overcome the problem, but the learning media provide various information that koprehensip to students.
\end{abstract}

Keywords: instructional media, student interest 


\section{PENDAHULUAN}

Peranan media pembelajaran dalam proses belajar dan mengajarmerupakan satu kesatuanyang tidak dapat dipisahkandaridunia pendidikan. Media pembelajaran merupakan segala sesuatu yang dapat digunakan untuk menyalurkan pesan pengirim kepada penerima, sehingga dapat merangsang pikiran, perasaan, perhatian, dan minat peserta didik untuk belajar.Senada dengan apa yang dikatakan oleh (Ruth Lautfer, 1999) bahwa media pembelajaran adalah salah satu alat bantu mengajar bagi guru untuk menyampaikan materi pengajaran, meningkatkan kreatifitas siswa dan meningkatkan perhatian siswa dalam proses pembelajaran. Dengan media siswa akan lebih termotivasi untuk belajar, mendorong siswa menulis, berbicara dan berimajinasi semakin terangsang. Dengan demikian, melaluimedia pembelajarandapat membuat proses belajar mengajar lebihefektif dan efesien serta terjalin hubungan baik antara guru dengan peserta didik. Selain itu, media dapat berperanuntuk mengatasi kebosanan dalam belajar di kelas.Oleh karena itu, guru dituntut memberikan motivasi pada peserta didik melalui pemanfaatan media yang tidak hanya ada di dalam kelas, akan tetapi juga yang ada di luar kelas, jika hal itu dimanfaatkan maka tujuan pembelajaran akan tercapai.Lantas apa yang terjadi jika media pembelajaran tidak ada, yang terjadi adalah mengalami kesulitan dalam mengajar, materi menjadi monoton dan siswa merasa bosan dengan apa yang diajar oleh pendidik. Oleh karena itu, media pembelajaran harus difungsikan untuk meningkatkan kualitas belajar mengajar.Dengan demikian semakin menarik media pembelajaran yang digunakan oleh guru akan semakin tinggi pula tingkat motivasi belajar siswa. Namun dalam prakteknya, masih banyak dijumpai guru-guru yang belum menerepankan media pembelajaran secara inovatif, bukan hanya tidak menerapkan media tersebut, namun sama sekali tidak ada media pembelajaran di sekolah. Ada beberapa alasan, mengapa guru tidak menggunakan media pembelajaran.Alasan pertama adalah (1). Guru menganggap bahwa menggunakan media perlu persiapan. (2). Media itu barang canggih dan mahal. (3). Tidak biasa menggunakan media (gagap teknologi). (4). Media itu hanya untuk hiburan sedangkan belajar itu harus serius. (5). Di sekolah tidak tersedia media tersebut, sekolah tidak memiliki peralatan dan bahan untuk membuat media pembelajaran. (6). Guru tidak memahami arti penting penggunaan media pembelajaran. (7). Guru tidak memiliki pengetahuan dan kemampuan mengenai cara membuat sendiri media pembelajaran. (8). Guru tidak memiliki keterampilan mempergunakan media pembelajaran. (9). Guru tidak memiliki peluang (waktu) untuk membuat media pembelajaran. (10). Guru 
sudah biasa mengandalkan metode ceramah.

Pada hal perkembangan Ilmu Pengetahuan dan Teknologi (IPTEK) saat ini sangat menolong para pendidik untuk lebih kreatif dalam membuat media pembelajaran.Sekalipun perkembangan Ilmu Pengetahuan dan Teknologi banyak memunculkan berbagai gejala sosial dan perubahan dalam masyarakat, namun bukan berarti para tenaga pendidik menghindari dan tidak mau mengikuti perkembangan yang ada.

Menurut Presiden Republik Indonesia dalam pembukaan Rapat Koordinasi Nasional Pengawasan Internal Pemerintah Tahun 2017 di Istana Negara, Kamis (18/5/017), Jokowi mengatakan, dunia berubah sedemikian cepatnya akibat teknologi, bahkan negara-negaralain sudah sedemikian rupa berbicara ruang angkasa, sedangkan orang Indonesia baru belajar menggunakan internet, belum lagiberkutat dengan demo, fitnah dan saling menghujatmelalui media sosial dengan menyebarkan berita-berita hoax. Oleh karena itu perlu kesiapan dari sumber daya manusia dalam mengatasi setiap problem yang ada.Salah satu cara mengatasinya permasalah yang ada adalahdiperlukan program pendidikan yang berkualitas, menyediakan berbagai pengetahuan, keterampilan dan nilai-nilai yang luwes, sehingga menghasilkan sumber daya manusia yang tangguh, mandiri tanggung jawab dalam menghadapi tantangan global. Itulah sebab, guru diharapkan mampu mengembangkan keterampilan membuat media pembelajarannya sendiri, karena perkembangan ilmu dan teknologi semakin mendorong ke arah pembaharuan.Oleh karena itu, berdasarkan prolem di atas, maka penulis memberi judul karya tulis ini yakni Peranan Media Pembelajaran dalam Proses belajar dan mengajar di Kalangan Mahasiswa STT Kadesi Yogyakarta. Karena media pembelajaran merupakan salah satu komponen pembelajaran yang mempunyai peranan sangat penting dalam proses pembelajaran.

Pemanfaatan media dalam pengajaran seharusnya merupakan bagian yang harus mendapat perhatian dari guru sebagai fasilitator dalam setiap kegiatan pembelajaran. Oleh karena itu setiap pendidik perlu mempelajari bagaimana memilih dan menetapkan media pembelajaran agar pencapaian tujuan pembelajaran dalam proses belajar mengajar dengan optimal. Sekalipun media pembelajaran ini masih sering diabaikan dengan berbagai alasan diantaranya.

\section{KAJIAN TEORITIS}

\section{Definisi Media Pembelajaran}

Nunu Mahnun (2012) menyebutkan bahwa "media" berasal dari bahasa Latin "medium" yang berarti "perantara" atau “pengantar".Lebih lanjut, media merupakan sarana penyalur pesan atau informasi 
belajar yang hendak disampaikan oleh sumber pesan kepada sasaran atau penerima pesan tersebut.Penggunaan media pengajaran dapat membantu pencapaian keberhasilan belajar. Menurut AECT (Association of Education and Communication Technology) yang dikutip oleh Basyaruddin (2002) "media adalah segala bentuk yang dipergunakan untuk proses penyaluran informasi”. Sedangkan menurut Steffi Adam dan Muhammad Taufik Syastra (2015) bahwa media pembelajaran adalah segala sesuatu baik berupa fisik maupun teknis dalam proses pembelajaran yang dapat membantu guru untuk mempermudah dalam menyampaikan materi pelajaran kepada siswa sehingga memudahkan pencapaian tujuan pembelajaran yang telah dirumuskan. Selanjutnya (Joni Purwono, dkk, 2014) menjelaskan bahwa media pembelajaran memiliki peranan penting dalam menunjang kualitas proses belajar mengajar. Media juga dapat membuat pembelajaran lebih menarik dan menyenangkan. Salah satu media pembelajaran yang sedang berkembang saat ini adalah media audiovisual. Dari pengertian di atas dapat disimpulkan bahwa media pembelajaran adalah alat bantudalam proses belajar mengajaruntuk merangsang pikiran, perasaan, perhatian dan kemampuan atau ketrampilan pembelajar sehingga dapat mendorong terjadinya proses belajar.

\section{Jenis-jenis Media Pembelajaran}

Perkembangan pendidikan yang sangat pesat, berpengaruh pada perkembangan psikologi belajar serta pada sistem pendidikan yang ada.Keadaan tersebut, mendorong dan berakibat juga pada kemajuan teknologi pembelajaran dan penambahan baru pada media pembelajaran.Seiring dengan kemajuan teknologi, maka perkembangan media pembelajaran begitu cepat, di mana masingmasing media yang ada punya ciri-ciri dan kemampuan sendiri. Dari hal ini, kemudian timbul usaha-usaha penataannya yaitu pengelompokkan atau klasifikasi menurut kesamaan ciri-ciri atau karakteristiknya. Ciri-ciri umum dari media pembelajaran menurut (Oemar Hamalik, 1994), adalah: Pertama, Media pembelajaran identik dengan pengertian peragaan yang berasal dari kata "raga", artinya suatu benda yang dapat diraba, dilihat dan didengar dan yang dapat diamati melalui panca indera. Kedua, Tekanan utama terletak pada benda atau hal-hal yang dapat dilihat dan didengar. Ketiga, Media pembelajaran digunakan dalam rangka hubungan (komunikasi) dalam pengajaran antara guru dan siswa. Keempat, Media pembelajaran adalah semacam alat bantu belajar mengajar, baik di dalam maupun di luar kelas. Kelima, Media pembelajaran merupakan suatu "perantara" (medium, media) dan digunakan dalam rangka belajar.Keenam, Media pembelajaran mengandung aspek, 
sebagai alat dan sebagi teknik yang erat pertaliannya dengan metode belajar. Ketujuh, Karena itu, sebagai tindakan operasional, dalam buku ini digunakan pengertian “media pembelajaran”.Selain ciri-ciri di atas, lalu apa saja yang termasuk dalam media pembelajaran. Menurut Rudi Bretz sebagaimana dikutip oleh (Arif Sadiman, 1993) yang membagi ke dalam 8 klasifikasi media, yakni: (1). Media audio visual gerak. (2). Media audio visual diam. (3). Media audio semi gerak. (4). Media visual gerak. (5). Media visual diam. (6). Media visual semi gerak. (7). Media audio. (8). Media cetak. Sedangkan menurut Briggs, (dalam Arif Sadiman, 1993) bahwa terdapat 13 macam media, yaitu : (1). Obyek. (2). Model. (3). Suara langsung. (4). Rekaman audio. (5). Media cetak. (6). Pembelajaran terprogram. (7). Papan tulis. (8). Media transparansi. (9). Film rangkai. (10). Film bingkai. (11). Film. (12). Televisi. (13). Gambar. Dari berbagai jenisjenis media yang dikemukakan di atas, maka dapat disimpulkan bahwa media pembelajaran adalah sarana, metode dan teknik yang digunakan dalam rangka mengidentifikasikan komunikasi dan interaksi antar dosen/guru dan peserta didik dalam proses pembelajaran di sekolah.

\section{Fungsi dan Peran Media Pembelajaran}

Setiap manusia memerlukan belajar untuk mengembangkan pengetahuan, bakat dan minatnya. Dalam pengembangan kemampuan tersebut, seseorang membutuhkan orang lain untuk mendidiknya. Selain itu, peran media juga sangat diperlukan dalam mendidik peserta didik. Hal ini dijelakan oleh (Iwan Falahudin, 2014) bahwa peran pembelajar adalah menyediakan, menunjukkan, membimbing dan memotivasi para pembelajar agar mereka dapat berinteraksi dengan berbagai sumber belajar yang ada. Bukan hanya sumber belajar yang berupa orang , melainkan juga sumbe-sumber belajar yang lain. Oleh karena itu, dalam meningkatkan kemampunya untuk belajar maka diperlukan sumber belajar. Dengan adanya sumber belajar maka peserta didik dapat mengerti apa yang dipelajarinya. Salah satu sumber belajar yang dikenal selama ini adalah media pembelajaran.Menurut AECT (dalam Ahmad Rohani, 1991), mengklasifikasikan tentang sumber belajar media menjadi enam macam, yaitu: (1). Message (pesan), yaitu informasi/ajaran yang diteruskan oleh komponen lain yang dalam bentuk gagasan, fakta, arti dan data. Termasuk dalam kelompok pesan adalah semua bidang studi/mata kuliah atau bahan pengajaran yang diajarkan kepada peserta didik, dan sebagainya. (2). People (orang), yakni manusia yang bertindak sebagai penyimpan, pengolah dan penyaji pesan. Termasuk kelompok ini misalnya guru/dosen, tutor peserta didik dan sebaginya. (3). Materials (bahan), yaitu perangkat lunak yang mengandung pesan 
untuk disajikan melalui penggunaan alat perangkat keras atau pun oleh dirinya sendiri. Berbagai program media termasuk media materials seperti transportasi, slide, film, audio, video, modul, majalah, buku dan sebagainya. (4). Device (alat), yakni (suatu perangkat keras) yang digunakan untuk menyampaikan pesan yang tersimpan dalam bahan, misalnya OHP, slide, video, tape recorder, dan sebagainya. (5). Technique (teknik), yaitu prosedur atau acuan yang dipersiapkan untuk penggunaan bahan, peralatan, orang, lingkungan untuk menyampaikan pesan. Misalnya pengajaran terprogram/modul, simulasi, demonstrasi, tanya jawab, CBSA, dan sebagainya. (6). Setting (lingkungan), yaitu situasi atau suasana sekitar di mana pesan disampaikan. Baik lingkungan fisik ruang kelas, gedung sekolah, perpustakaan, laboratorium, taman, lapangan, dan sebagainya. Juga lingkungan non fisik, misalnya suasana belajar itu sendiri, tenang, lelah, ramai dan sebagainya.

Pada dasarnya, media adalah sebagai alat komunikasi yang digunakan dalam proses belajar mengajar. Sebagai alat komunikasi, media pembelajaran menurut (Oemar Hamalik, 1994) memiliki fungsi yang luas di antaranya: (a). Fungsi edukatif media komunikasi, yakni bahwa setiap kegiatan media komunikasi mengandung sifat mendidik karena di dalamnya memberikan pengaruh pendidikan. (b). Fungsi sosial media komunikasi, media komunikasi memberikan informasi aktual dan pengalaman dalam berbagai bidang kehidupan sosial orang. (c). Fungsi ekonomis media komunikasi, media komunikasi dapat digunakan secara intensif pada bidang-bidang pedagang dan industri. (d). Fungsi politis media komunikasi, dalam bidang politik media komunikasi dapat berfungsi terutama politik pembangunan baik material maupun spiritual. (e). Fungsi seni dan budaya media komunikasi, perkembangan ke bidang seni dan budaya dapat tersebar lewat media komunikasi. Dari sekian fungsi media pembelajaran di atas, (Arif Sadiman,1993),menguraikan beberapa fungsi media pembelajaran, yaitu: (a). Memperjelas penyajian pesan agar tidak terlalu bersifat verbalistik (dalam bentuk kata-kata tertulis atau lisan belaka). (b). Mengatasi keterbatasan ruang, waktu, dan daya indera, seperti misalnya:1) Obyek yang terlalu besar bisa digantikan oleh realita, gambar, film, atau model. 2) Obyek yang kecil dibantu oleh proyektor mikro, film bingkai, film atau gambar. 3) Gerak yang terlalu lamban atau terlalu cepat, dapat dibantu dengan timelapse atau hagh speed photograpy. 4) Kejadian atau peristiwa yang terjadi di masa lalu bisa ditampilkan lagi lewat rekaman film, video, film bingkai, foto atau pun secara verbal. 5) Obyek yang terlalu kompleks (missal mesin-mesin) dapat disajikan dengan model, diagram dan lain-lain. 6) Konsep 
yang terlalu luas (gunung berapi, gempa bumi, iklim dan lain-lain) dapat divisualisasikan dalam bentuk film, film bingkai, gambar dan lain-lain. (c). Penggunaan media pembelajaran secara tepat dan bervariasi dapat diatasi sikap pasif anak didik, dalam hal ini media pembelajaran berguna untuk:1). Menimbulkan kegairahan belajar.2). Memungkinkan belajar interaksi yang lebih langsung antara anak didik dengan lingkungan dan kenyataan.3). Memungkinkan anak didik belajar sendirisendiri menurut kemampuan dan minatnya. (d). Dengan sifatnya yang unik pada tiap siswa, ditambah lagi dengan lingkungan dan pengalaman yang berbeda, sedangkan kurikulum dan materi pendidikan ditentukan sama untuk setiap siswa, maka akan banyak mengalami kesulitan bilamana semuanya itu harus diatasi sendiri, apalagi bila latar belakang lingkungan guru dengan siswa juga berbeda. Masalah ini, dapat diatasi dengan kemampuan dalam: 1) Memberikan rangsangan yang sama. 2) Mempersamakan pengalaman. 3) Menimbulkan persepsi yang sama. Dari uraian di atas, jelaslah bahwa fungsi media pembelajaran sangat berpengaruh terhadap pencapaian tujuan yang telah ditetapkan dalam pendidikan.

Peranan media pembelajaran dalam proses belajar dan mengajar sangat penting dilaksanakan oleh para pendidik saat ini, karena peranan media pembelajaran dapat digunakan untuk menyalurkan pesan pengirim kepada penerima dan melalui media pembelajaran juga dapat membantu peserta didik untuk menjelaskan sesuatu yang disampaikan oleh pendidik. Dengan penggunaan alat-alat ini guru dan siswa dapat berkomunikasi lebih mantap dan hidup serta interaksinya bersifat banyak arah. Media mengandung pesan sebagai perangsang belajar dan dapat menumbuhkan motivasi belajar sehingga siswa tidak menjadi bosan dalam meraih tujuan-tujuan belajar (Putra Sumberharjo, dkk, 2015). Ada beberapa peranan media pembelajaran dalam proses belajar antara lain:

Pertama, mahasiswa memiliki kemampuan untuk menangkap pembelajaran dengan baik.Dengan demikian penggunaan media dalam pengajaran di kelas merupakan sebuah kebutuhan yang tidak dapat diabaikan. Karena media pembelajaran adalah sumber belajar, secara luas media dapat diartikan dengan manusia, benda atau pun peristiwa yang membuat kondisi siswa untuk lebih memungkinkan memperoleh pengetahuan keterampilan atau pun sikap (Mudhofir, 1993). Kedua, Media membangkitkan keinginan dan minat mahasiswa untuk belajar.Bukan hanya membangkitkan motivasi untuk belajar, namun membawa pengaruh positif bagi psikologis mahasiwa.Sebab mediapembelajaran dapat memperlancar interaksi antara dosen/guru 
dengan peserta didik.Ketiga, Media memiliki kemampuan untuk menampilkan kembali objek atau kejadian dengan berbagai macam cara disesuaikan dengan keperluan dan penuh makna.Selain urain di atas, (Sidik Bagas, 2018) menambahkan peranan media pembelajaran dalam proses pembelajaran antara lain: (1). Memperjelas penyajian materi agar tidak hanya bersifat verbal (dalam bentuk kata-kata tertulis atau tulisan). (2). Mengatasi keterbatasan ruang, waktu dan daya indera. (3). Penggunaan media secara tepat dan bervariasi dapat mengatasi sifat pasif anak didik. (4). Menghindari kesalahpahaman terhadap suatu objek dan konsep. (5). Menghubungkan yang nyata dengan yang tidak nyata.

Jadi, dengan menggunakan media pembelajaran dalam proses belajar membantu untuk memperlancar interaksi antara pendidik dengan peserta didik sehingga kegiatan pembelajaran akan lebih efektif dan efisien dalam meningkatkan mutu pendidikan.

Salah satu tujuan pendidikan nasional adalah mencerdaskan kehidupan bangsa. Dalam Undang-Undang Republik Indonesia No. 20 Tahun 2003 Bab II Pasal 3, Pendidikan Nasional bertujuan untuk: mengembangkan potensi peserta didik agar menjadi manusia yang beriman dan bertaqwa kepada Tuhan Yang Maha Esa, berakhlak mulia, sehat, berilmu, cakap dan kretif, mandiri dan menjadi warga yang demokratis serta bertanggung jawab". Dalam mewujudkan tujuan tersebut maka diperlukan kegiatan pendidikan formal dan non formal. Pendidikan yang dilaksanakan di kampus/sekolah merupakan tempat mencari ilmu bagi peserta didik, serta tempat bagi dosen/guru mentransfer ilmupengetahuannya kepada peserta didik. Oleh karena itu, dalam meningkatkan kualitas pengajaran seorang dosen/guru maka diperlukan media pembelajaran. Dalam zaman modern ini, dosen/guru dituntut untuk menggunakan media pembelajaran dalam menyampaikan materi di dalam kelas. Sebab media pembelajaran adalah salah satu komponen pembelajaran yang mempunyai peranan penting dalam proses pembelajara. Oleh sebab itu, pemerintah mendorong para dosen atau guru untuk menfaatkan media pembejaran dalam meningkatkan kuliatas mengajar. Dengan menggunakan media pembelajaran seharusnya merupakan bagian yang harus mendapat perhatian dosen atau guru. Menurut hemat (J. Reginald Hill, 1998) bahwa melalui media alat peraga peserta didik akan belajar lebih bersemangat dan dapat mengingat dengan lebih baik pembelajaran yang sudah diajarkan oleh dosen/guru. Oleh karena itu tiap-tiap pendidik perlu mempelajari bagaimana menetapkan media pembelajaran agar dapat mengefektifkan pencapaian tujuan pembelajaran dalam proses belajar mengajar. Selain penjelasan di atas, peranan 
media pembelajaran dalamproses belajar mengajar antara lain: (1). Dapat menghindari terjadinya verbalisme. (2). Membangkitkan minat atau motivasi. (3). Menarik perhatian. (4). Mengatasi keterbatasan ruang, waktu dan ukuran. (5). Mengaktifkan siswa dalam belajar. (6). Mengefektifkan pemberian rangsangan untuk belajar.Sedangkan menurut (Nana Sudjana, 1995) bahwa peranan media pembelajaran dalam proses mengajar adalah sebagai berikut:

Pertama, Penggunaan media dalam proses mengajar bukan merupakan fungsi tambahan, tetapi mempunyai fungsi sendiri sebagai alat bantu untuk mewujudkan situasi belajar mengajar yang efektif. Kedua, Penggunaan media pengajaran merupakan bagian yangintegral dari keseluruhan situasi mengajar. Ini berarti bahwa media pengajaran merupakan salah satu unsur yang harus dikembangkan guru. Keempat, Media dalam pengajaran penggunaannya bersifat integral dengan tujuan dan isi pelajaran. Kelima, Penggunaan media bukan semata-mata sebagai alat huburan yang digunakan hanya sekedar melengkapi proses belajar supaya lebih menarik perhatian siswa. Keenam, Penggunaan media dalam proses pembelajaran lebih diutamakan untuk mempercepat proses belajar dan membantu siswa dalam menagkap pengertian yang diberikan guru. Ketujuh, Pengguna media dalam pengajaran diutamakan untuk mempertinggi mutu belajar mengajar.

Berdasarkan uraian dan penjelasan para ahli di atas, penulis menyimpulkan bahwa media pembelajaran dapat membantu guru untuk menciptakan suana belajar menjadi lebih hidup, tidak monoton dan tidak membosankan.Artinya dosen/guru dapat menciptakan berbagai situasi kelas, menentukan berbagai macam metode pengajaran dan menciptakan iklim emosional yang sehat diantara peserta didik.

Ketiga, Peranan media pembelajaran dalam meningkatkan daya minat belajar Mahasiswa/peserta didik.

Sejak dipercayakan sebagai pengampu mata kuliah media pembelajarandi STT Kadesi Yogyakarta menjadi beban tersendiri, karena mengingat perkembangan teknologi di zaman modern ini begitu besar pengaruhnya dalam dunia pendidikan. Menurut hemat (Rahmayanti, 2015) bahwa "teknologi pembelajaran terus mengalami perkembangan seiring dengan perkembangan zaman.Dalam pelaksanaan pembelajaran sehari-hari kita sering menjumpai adanya pemfaatan dari perkembangan Teknologi dalam dunia pendidikan, seperti yang sering dilakukan oleh guru ataudosen yaitu mengkombinasikan alat teknologi dalam peroses pembelajaran. Artinya dalam penggunaan media pembelajaran dan teknologi dapat menolong peserta didik untuk mengerti materi yang disampaikan oleh guru atau dosen.Jika hal ini diabaikan oleh para pengajar saat inimaka peserta didik akan ketinggal banyak informasi. Dengan demikian kemampuan dan 
kompetensi dosen/guru dapat berperan penting dalam menyelesaikan berbagai polemik berkaitan dengan kegiatan belajar mengajar. Menurut (Nasir Usman, 2012) ada 10 dasar kompetensi dosen yang harus di miliki oleh dosen/guru sebagai syarat menjadi dosen yang professional, adalah sebagai berikut:

(1), Menguasai bahan (mata kuliah yang diajarkan). (2), Mengelola program belajar mengajar (dari persiapan perangkat mengajar sampai melaksanakan program belajar mengajar). (3), Mengelola kelas (mengatur tata ruang kelas dan menciptakan iklim belajar mengajar yang sesuai). (4), Menggunakan Media/sumber belajar (mengenal, memilih dan menggunakan media yang bervariatif, membuat alat-alat bantu pelajaran yang sederhana, menggunakan dan mengelola laboratorium,perpustakaan, dan micro-teaching yang disesuaikan dengan bidang studi yang diajarkannya). (5), Menguasai landasan-landasan kependidikan. (6). Mengelola interaksi belajarmengajar. (7). Menilai prestasi mahasiswa untuk kepentingan pembelajaran. (8). Mengenal fungsi dan program pelayanan bimbingan dan penyuluhan. (9). Mengenal dan menyelenggarakan administrasi sekolah. (10). Memahami prinsipprinsip dan menafsirkan hasil-hasil penelitian pendidikan guna keperluan pembelajaran.

Pada lingkungan kampus, dosen atau guru harus membangkitkan minat belajar siswa, karena itu adalah tugas para pendidik. Dosen atau guru harus benarbenar menguasai semua keterampilan yang dibutuhkan dalam pengajaran, antara lain menguasai materi, memiliki media pembelajaran yang menarik dan bervariasi. Jika dosen atau guru tidak menggunakan variasi dalam proses pembelajaran, peserta didik akan cepat bosan dan jenuh terhadap materi pelajaran.

Lantas apa yang dapat meningkatkan minat belajar mahasiswa dalam proses belajar mengajar, yakni: (1). Dosen/guru hendaklah menggunakan variasi dalam mengajar agar semangat dan minat mahasiswa dalam belajar meningkat sehingga prestasi belajar sesuai dengan yang diharapkan. (2). Dosen/guru membantu peserta didik/siswa melihat bagaimana hubungan antara materi yang diharapkan untuk dipelajarinya dengan dirinya sendiri sebagai individu (Sofan \&Elisah, Tatik, 2011). (3). Dosen/guru berusahamelibatkan peserta didik dalam kegiatan belajar mengajar di dalam kelas khususnya dalam meprestasi tugas di depan kelas. Dengan adanya tugas presentasi baik perorangan maupun individu mahasiswa memiliki gairah untuk belajar.Pengalaman penulis selama menjadi dosen, penulis merasa bahwa tugas presentasi yang diberikan kepada mahasiswa sangat penting, karena mahasiswa tersebut ada minat untuk belajar. (4). Dosen/guru yang menggunakan media pembelajaran, pada dasarnya mahasiswa lebih cepat menangkap penjelasan dosen dan bukan hanya itu, tetapi mahasiswa dapat menambah minat belajar dan memudahkan untuk mengerti tentang materi yang ada.Akibat dari sekian 
uraian di atas maka dapat dilihat ciri-ciri mahasiswa yang memiliki minat belajar.Pertama, mereka memahami tujuantujuan belajar. Kedua, merekamerasakan dan menemukan suasana pembelajaran yang menantang, merangsang dan menyenangkan.Ketiga, mereka memiliki keinginan tinggi untukberinteraksi baik kepada sesamanya maupun kepada dosen.Keempat, mereka merasa nyaman belajar sekalipun materinya susah dipahami.

Ada beberapa faktor yang mempengaruhi minat belajar mahasiwa atau peserta didik. (Menurut Taufani 2008), ada tiga faktor yang mendasari timbulnya minat yaitu:

(1). Faktor dorongan dalam, yaitu dorongan dari individu itu sendiri, sehingga timbul minat untuk melakukan aktivitas atau tindakan tertentu untuk memenuhinya. Misalnya, dorongan untuk belajar dan menimbulkan minat untuk belajar. (2). Faktor motivasi sosial, yaitu faktor untuk melakukan suatu aktivitas agar dapat diterima dan diakui oleh lingkungannya. Minat ini merupakan semacam kompromi pihak individu dengan lingkungan sosialnya.Misalnya, minat pada studi karena ingin mendapatkan penghargaan dari orangtuanya. (3). Faktor emosional, yakni minat erat hubungannya dengan emosi karena faktor emosional selalu menyertai seseorang dalam berhubungan dengan objek minatnya. Kesuksesan seseorang pada suatu aktivitas disebabkan karena aktivitas tersebut menimbulkan perasaan suka atau puas, sedangkan kegagalan akan menimbulkan perasaan tidak senang dan mengurangi minat seseorang terhadap kegiatan yang bersangkutan.

Berdasarkan urain tersebut di atas maka perlu adanya pengamatan secara langsung, apakah mahasiswa/pesrta didik memiliki minat belajar atau tidak. Oleh karena itu, (Rasyid 2010) menguraikan ada beberapa bukti jika anak-anak tersebut memiliki belajar, yakni: (1) bergairah untuk belajar, (2) tertarik pada pelajaran, (3) tertarik pada guru, (4) mempunyai inisiatif untuk belajar, (5) kesegaran dalam belajar, (6) konsentrasi dalam belajar, (7) teliti dalam belajar, (8) punya kemauan dalam belajar, (9) ulet dalam belajar.

\section{KESIMPULAN}

Perkembangan teknologi yang semakin canggih menjadi sarana untuk mencapai tujuan pendidikan. Itu sebabnya peranan media pembelajaran dalam proses belajar dan mengajarmerupakan satu kesatuanyang tidak dapat dipisahkandaridunia pendidikan. Media pembelajaran merupakan segala sesuatu yang dapat digunakan untuk menyalurkan pesan pengirim kepada penerima, sehingga dapat merangsang pikiran, perasaan, perhatian, dan minat peserta didik untuk belajar. Oleh karena itu,dosen/guru dituntut memberikan motivasi pada peserta didik melalui pemanfaatan media yang tidak hanya ada di dalam kelas, akan tetapi juga yang ada di luar kelas, jika hal itu dimanfaatkan maka tujuan pembelajaran 
akan tercapai. Lantas apa yang terjadi jika media pembelajaran tidak ada, yang terjadi adalah pertama, mengalami kesulitan dalam mengajar, materi menjadi monoton dan peserta didik merasa bosan dengan apa yang diajar oleh pendidik. Kedua, peserta didik sulit mengerti dan memahami materi pembelajaran. Ketiga, peserta didik susah menangkap penjelasan dari dosen/guru. Keempat, peserta didik merasan bosan dengan materi tersebut. Kelima, peserta didik susah berpikir.

Sebagai saran demi kelancaran dan efektivitas pembelajaran di kelas maka media pembelajaran salah satu alat bantu/sumber belajar untuk meningkatkan daya minat belajar peserta didik. Oleh karena itu, para guru/dosen sebaiknya memfungsikan media pembelajaran dengan baik. Lebih lanjut, alat bantu/media/sumber belajar perlu dimanfaatkan secara sinergis untuk mengoptimalkan pembelajaran. Dengan adanya media/alat bantu pembelajaran semakin memudahkan guru/dosen dalam pelaksanaan pembelajaran. Sehingga dapat menciptakan kondisi yang dapat mendorong siswa agar dapat mencapai kompetensinya dalam pembelajaran yang diberikan oleh guru atau dosen.

\section{DAFTAR PUSTAKA}

Adam. Steffi dan Muhammad Taufik Syastra. (2015). Pemanfaatan Media Pembelajaran Berbasis Teknologi Informasi Bagi Siswa Kelas X Sma Ananda Batam. Dalam CBIS Journal, Volume 3 No 2: 79
Asnawir dan M. Basyiruddin Usman. (2002). Media Pembelajaran, Jakarta: Ciputat Pers.

Falah. Iwan, Pemanfaatan Media dalam Pembelajaran. Dalam Jurnal Lingkar Widyaiswara Edisi 1 No. 4:104-117

Hamalik, Oemar. (1994). Media Pendidikan, Bandung: Citra Adtya Bakti.

Hill. Reginald. (1998). Penuntun Sekolah Minggu, Jakarta: Yayasan Komunukasi Bina Kasih.

Lautfer. Ruth. (1993). Pedoman Pelayanan Anak.Malang Indonesia : Yayasan Persekutuan Pekabaran Injil Indonesia.

Mahnun.Nunu.(2012). Media Pembelajaran (Kajian terhadap Langkah-langkah Pemilihan Media dan Implementasinya dalam Pembelajaran). Dalam Jurnal Pemikiran Islam; Vol. 37, No. 1: 27.

Mudhofir. (1993). Teknologi Intruksional, Bandung: Remaja Rosda Karya.

Purwono. Joni, dkk. (2014). Penggunaan Media Audio-Visual Pada Mata Pelajaran Ilmu Pengetahuan Alam Di Sekolah Menengah Pertama Negeril Pacitan. Dalam Jurnal Teknologi Pendidikan dan Pembelajaran Vol.2, No.2: 127

Rahmayanti. (2015). Penggunaan Media It Dalam Pembelajaran. Dalam urnal Ilmiah CIRCUIT Vol. 1 No. 1 Juli: 92.

Rohani, Ahmad. (1991). Pengelolaan Pelajaran, Jakarta: Rineka Cipta.

Rasyid.(2010). Minat, Indikator-Indikator Minat. Jakarta: Bumi Aksara.

Sofan \&Elisah, Tatik. (2011). Strategi Pembelajaran Sekolah. Terpadu. Jakarta: PT. Prestasi Pustaka.

Sudjana.Nana.(1995). Dasar-Dasar Proses Belajar Mengajar. Bandung: Sinar Baru Algensindo.

Sumberharjo. Putra, dkk. (2015). Media Pembelajaran Pengenalan Huruf Dan Angka Di Taman Kanak-Kanak Tunas. Dalam Journal Speed - Sentra Penelitian Engineering dan Edukasi - Volume 7 No $3: 24$

Taufani.(2008). Minat. Faktor-Faktor yang Mempengaruhi. Jakarta: Rineka Cipta. 
Usman.Nasir. (2012). Manajemen Peningkatan Mutu Kinerja Guru (konsep,Tiori dan
Model), Bandung, Cita Pustaka. 